\title{
A Review Study of Grid-Connected SVPWM System Analysis and Control of Quasi-Z Source Inverter: Comparative Analysis of MPPT in Solar Panel with Respect to Power
}

\author{
Ghulam Rabani ${ }^{1}$,Shekhar Verma ${ }^{2}$ \\ ${ }^{2}$ Assistant Professor, Department of Electrical Engineering, EMAX Group of Colleges, Haryana, India
}

\begin{abstract}
The most extreme power conveyance to the heap is guaranteed by a versatile neuron fuzzy deduction framework (ANFIS) in view of greatest power point following framework (MPPT). The ANFIS-based MPPT offers a to a great degree quick element reaction with high precision framework. An altered space vector modulation (SVPWM) method for the qZSI is connected to accomplish low noise, high voltage usage, power variable change and high effectiveness. The paper described the detail analysis of literature survey related to topic.
\end{abstract}

Keywords:MPPT, PV characteristics, SVPWM Solar Panel, Solar energy, Temperature

\section{Introduction}

$\mathrm{Z}$ source inverters are late inverter topologies that can perform both buck and help capacities as a solitary unit (Fang Zheng Peng 2003). An extraordinary component of Z source inverter is the shoot through state, by which two quasi conductor switches of the same stage leg can be turned $\mathrm{ON}$ at the same time. In this way, no dead time is required and outcome contortion is extraordinarily decreased and accordingly unwavering quality is enormously made strides. This component is not accessible in the conventional voltage source and current source inverters. $\mathrm{Z}$ source inverters are for the most part connected for burdens that request a high voltage increase, for example, engine drives and as a power molding unit for renewable energy sources like solar light based, energy components, and so on to coordinate the information source voltage contrasts [1].

The improvement in $\mathrm{Z}$ source inverter topologies gives a back to back upgrade in voltage pick up and outcome waveforms. A tradeoff between the boosting ability and part check is dependably a noteworthy worry to keep the cost stable. It is to be noticed that increment in the latent parts with reasonable adjustments can enhance the execution of these sorts of inverters. The topological development has been as far as expansion or diminishment of uninvolved segment, consideration of additional quasi conductor switches, adjustment or incorporation of $\mathrm{dc}$ sources furthermore changes of tweak plans and so forth [2]. Voltage buck reversal capacity is additionally accommodated those applications that need low air conditioning voltages.

It is additionally noticed that this topological development has prompted enhanced outcome attributes dependable for different operations. There are additionally situations where a particular topology is changed for an extraordinary application. This manageable development has pulled in analysts to present certain one of kind models of $\mathrm{Z}$ source inverters and its variations are talked about in this theory. All the proposed $\mathrm{Z}$ source inverter topologies are intended for photovoltaic frameworks, controlled by switching plans viz., sinusoidal PWM space vector PWM and basic help PWM. Exhibitions of the chose proposed topologies are approved through downsized laboratory prototype [3].

\section{Literature Review}

\section{A. Review Based on Analysis of Solar Photovoltaic} Systems

A methodology is made by Sera et al (2007) to exhibit the development of PV board model utilizing the single diode five parameter models, solely in light of information sheet parameters to anticipate the board conduct in various temperature and irradiance conditions. Patel and Agarwal (2008) exhibited a MATLAB based test system cum learning apparatus, to improve the comprehension and to anticipate the qualities of expansive PV clusters under halfway shading conditions [4].

A circuit model was proposed by Marcelo Gradella Villalva et al (2009) for use in recreations of photovoltaic (PV) frameworks to get the execution qualities of the photovoltaic modules. Abir Chatterjee et al (2011) introduced a PV model estimation technique from the PV module information in light of a solitary diode model of a PV cell to gauge the parameters of exhibits with change in temperature and irradiance. The impact of incomplete shading on multi crystalline silicon (mc-Si) PV modules was concentrated on through P-Spice simulation model by Evagelia Paraskevadaki et al (2011) to measure the impact of halfway shading on the $\mathrm{I}-\mathrm{V}$ bend and the most extreme power point (MPP) voltage and control and accepted the model by means of exploratory results [5].

The prior endeavor to examine diverse inverter topologies was talked about, and they are quickly reported in the study work by Keith Corzine et al (2004), Mariusz Malinowski et al (2010) and Jose Rodriguez et al (2002, 2010). In these overview works, topologies control and uses of various sorts 


\section{International Journal of Science and Research (IJSR) \\ ISSN (Online): 2319-7064}

Index Copernicus Value (2013): 6.14 | Impact Factor (2015): 6.391

of inverters proposed by different analysts for some applications are reported [6].

\section{B. Review Based on Topological Analysis of $\mathrm{Z}$ Source Inverters}

Fang Zheng Peng et al (2005) showed Z source inverter framework for customizable velocity drives (ASD) to have ride through capacity under voltage droops, lessened line noise, and augmented outcome voltage range with recreation and trial results. A two level voltage sort $\mathrm{Z}$ source inverter for photovoltaic frameworks was proposed by Yi Huang et al (2006) to acknowledge reversal and support capacity in one single stage with outline rule utilizing straightforward help control as switching plan [7].

Simulation and downsized lab model of three level $\mathrm{Z}$ source impartial point cinched inverter utilizing a solitary LC impedance system was exhibited by Poh Chiang Loh et al (2007). Configuration of a double $\mathrm{Z}$ source inverter utilized with either a solitary dc source or two disengaged dc sources was proposed by Feng GAO et al (2007). Hypothetical discoveries, together with the inverter common sense of the double $\mathrm{Z}$ source inverter was affirmed in simulations both utilizing PSIM with MATLAB/Simulink coupler and tentatively by utilizing a research facility executed inverter model [8].

Poh Chiang Loh et al (2008) displayed the advancement of two three level fell $\mathrm{Z}$ source inverters with maybe a couple impedance systems in the front end controlled utilizing distinctive regulation methodologies, for example, stage demeanor and stage moved transporter switching plans [9].

Zhi Jian Zhou et al (2008) exhibited Z source inverter based uninterruptible power supply (UPS) and contrasted its execution and customary UPS through recreation and exploratory results. Diode helped Cuk/SEPIC inferred buck support voltage source inverters was proposed by Feng Gao et al (2009) for delivering a voltage pick up nearly higher than those of other buck help change procedures through trial results. Another variable pace WECS with a PMSG and $\mathrm{Z}$ source inverter was produced by Dehghan et al (2009) for most extreme power following control and additionally conveying energy to the matrix, checked through simulation [10].

Chandana Jayampathi Gajanayake et al (2010) proposed four new groups of amplified support qZSI topologies, for example, diode helped or capacitor helped in view of the operation and the discrete part utilized in that upheld with simulation and exploratory acceptance. A bidirectional $\mathrm{Z}$ source nine switch inverter based mixture electric vehicle (HEV) was proposed by Dehghan et al (2010) which has two air conditioning and one dc bidirectional terminals and its execution was checked by both recreation and exploratory results. Five level $\mathrm{Z}$ source diode braced inverter outlined with two halfway $\mathrm{Z}$ source systems associated between the dc information sources and backside inverter hardware was distinguished by Gao et al (2010). Downsized research center model had been executed to check its hypothetical discoveries and reasonable issues, upheld with simulation results [11].
Operation of single stage incitement engine drive framework utilizing Z source inverter was shown by Rajaei et al (2010) through recreation and exploratory checks. Another group of installed $\mathrm{Z}$ source inverters was proposed by Poh Chiang Loh et al (2010), which were actualized utilizing an impedance system with the pertinent dc sources inserted inside, to have a smoother current drawn from the dc information sources without utilizing outer second request channels with downsized research facility model [12]

A novel switched inductor $\mathrm{Z}$ source inverter was introduced by Miao Zhu et al (2010) to enhance the current traditional Z source inverter controlled utilizing basic support and most extreme help control as switching plan with downsized research center model. Minh-Khai et al (2011) proposed a novel switched inductor quasi $\mathrm{Z}$ source inverter by lessening detached part number furthermore diminished voltage weight on capacitors, lower current weight on inductors and diodes [13].

Immediate and substitute fell systems were utilized for the current two and three level $\mathrm{Z}$ source inverters and its execution were seen through simulation and exploratory results by Ding Li et al (2011). A two level voltage sort enhanced $\mathrm{Z}$ source inverter was proposed by $\mathrm{Yu}$ Tang et al (2011) for standalone PV frameworks utilizing basic support control as switching plan. Recreation and trial approval were done for deviated and symmetrical implanted $\mathrm{Z}$ source inverters by Gao et al (2011) for the applications like photovoltaic and power device energy saddling [14].

The execution of current bolstered quasi ZSI was considered by Yang et al (2011) through changed space vector beat width regulation strategy in opposite blocking; protected door bipolar transistor based current sustained qZSI with downsized research facility model. Anderson et al (2008) created four quasi $\mathrm{Z}$ source inverters which have focal points, for example, lower segment evaluations, decreased source stress, diminished segment tally and disentangled control procedures suited for engine controllers or renewable energy applications [15].

Quasi Z source inverter for photovoltaic power generation frameworks was exhibited by Yuan Li et al (2009) with configuration rule through recreations and analyses. A three level AC-DC-AC Z source converter with outcome voltage buck support capacity was exhibited by Poh Chiang Loh et al (2009), by associating an ease front-end diode rectifier to a nonpartisan point clasped inverter through a solitary $\mathrm{X}$ molded LC impedance system [16].

For affirming the converter execution, trial testing utilizing a built research center model was performed. Keping You et al (2009) proposed another lattice $Z$ source converter utilizing framework converter speculations and $\mathrm{Z}$ source change ideas and delineates its application for the coordinated starter/alternator (ISA) framework by a contextual investigation. This work researches the quadrant operation of the converter, control, its enduring state execution, and trial confirmation. Another $\mathrm{Z}$ source nine switch inverter which can control sufficiency, recurrence, and period of both AC outcomes furthermore control current of both DC inputs was displayed by Dehghan et al (2010). Execution of the 


\section{International Journal of Science and Research (IJSR) \\ ISSN (Online): 2319-7064}

Index Copernicus Value (2013): 6.14 | Impact Factor (2015): 6.391

proposed inverter was checked by simulation and trial results [17].

The execution change technique for voltage bolstered consistent information current quasi impedance source inverter (qZSI) was proposed by Vinnikov et al (2010) with the presentation of two-phase quasi $\mathrm{Z}$ source system (qZS system) through simulation and test setup. Another expanded support qZSI and a straightforward balance control technique taking into account one cycle control was proposed by Gajanayake et al (2009) for controlling a lattice associated power module energy framework, broadly recreated in MATLAB/Simulink environment. Enduring state investigation of two broadened help qZSI's topologies was talked about by Vinnikov et al (2010) and its exhibitions were tentatively accepted in nonstop conduction working mode [18].

Zakis et al (2011) displayed simulation and exploratory consequences of a qZSI based bidirectional DC/DC converter for super capacitor interfacing. Hypothetical suppositions were demonstrated by the PSIM simulation comes about and confirmed tentatively. The idea of quasi $\mathrm{Z}$ source based detached DC/DC converters for disquasinated power generation were exhibited with operation standards by Vinnikov et al (2010) through trial results. Yu Tang et al (2011) proposed a novel single stage $Z$ source inverter topology with info and outcome having the same ground, which was straightforward in structure and just uses two switches while keeping the voltage exchange proportion the same concerning the full extension inverter receiving one cycle control methodology [19].

A vigorous and solid lattice power interface framework for wind turbines utilizing a lasting magnet synchronous generator (PMSG) with an incorporation of a generator side three switch buck sort rectifier and a matrix side $\mathrm{Z}$ source inverter was displayed by Shao Zhang et al (2011). The exhibitions and items of common sense of the planned engineering were checked by simulations and investigations. An altered Z source inverter (ZSI) with particular balance methods to diminish spillage streams in three-stage transformer less photovoltaic (PV) frameworks was proposed by Fabricio Bradaschia et al (2011). Test consequences of spillage streams in three-stage ZSIs associated with a RL burden were acquired to approve the hypothetical and simulation models [22].

\section{Review Based on Design and Modulation Scheme Analysis of $\mathbf{Z}$ Source Inverters}

Gajanayake et al (2005) displayed dynamic little signal demonstrating of the $\mathrm{Z}$ source impedance system utilizing irritated numerical examination and a sign stream diagram with parasitic parts. Utilizing the graphical sign stream demonstrating approach, different aggravation to-outcome exchange capacities were inferred with their parameter affectability. Most extreme support control was utilized for $\mathrm{Z}$ source inverter to deliver the greatest voltage help under a given balance list and its different related parameters were broke down by Fang Zheng Peng et al (2005) through simulations and trial checks [25].
Miaosen Shen et al (2006) proposed two steady support control strategies for the $\mathrm{Z}$ source inverter, to acquire most extreme voltage pick up at any given regulation record without creating any low recurrence swell, checked through recreation and trial acceptance. A study was made by Quang Vinh Tran et al (2007) to accomplish great execution for both dc help and air conditioning outcome voltage control of the ZSI through a changed space vector beat width regulation plan, by simulation and examinations utilizing a 32-bit advanced sign processor [14].

Fang Zheng Peng et al (2007) exhibited Z source inverter to control power from the energy unit, energy to the engine, and condition of charge of the battery in a power module based cross breed electric vehicles by simulation and exploratory results [15]. Transient demonstrating and examination of a voltage sort $\mathrm{Z}$ source inverter was introduced by Poh Chiang Loh et al (2007). Simulation and trial aftereffects of the same were gotten utilizing an switching useful model based research center model. The execution of $\mathrm{Z}$ source inverter with traditional heartbeat width adjustment (PWM) inverter and dc-dc helped PWM inverter for energy component vehicle applications were looked at by Miaosen Shen et al (2007) [16].

Loh et al (2007) displayed a combination of buck-support Z source power change idea to the present source inverter topology to create single and three stage $\mathrm{Z}$ source current source inverters by assessing distinctive bearer based reference definitions to distinguish diverse inverter state arrangement potential outcomes with recreation, and exploratory results. Near assessment of heartbeat width tweak methodologies for $\mathrm{Z}$ source impartial point clipped inverter was made by Poh Chiang Loh et al (2007) through simulation and downsized research center model [17].

Topological and adjustment configuration of three level $\mathrm{Z}$ source inverters were concentrated on by Poh Chiang Loh et al (2008) with few proposed control systems. Demonstrating and outline of a shut circle controller for $\mathrm{Z}$ source inverter for power transformation was introduced by Gajanayake et al (2007) in conveyed era (DG) applications, especially by wiping out the requirement for a two phase change. The simulation results were acquired utilizing a state spacefound the middle value of inverter model, and an exploratory model was worked to check its execution [18].

Little signal displaying and investigation of source converter (ZSC) in ceaseless conduction mode was made by Jingbo Liu et al (2007). Air conditioning little signals model of ZSC was determined and PC simulation results were utilized to approve the little signal demonstrating strategy. Different utilizations of the air conditioner little signal models to ZSC outline and trial checks were likewise displayed [19].

$\mathrm{Z}$ source current sort inverter with buck support highlight was proposed by Poh Chiang Loh et al (2008) for matrix interfacing with polices or three-stage compensators before the inverter beat width modulator for damping activated resounding motions. These discoveries have been affirmed both in recreations and tests utilizing an actualized research facility model [20]. 


\section{International Journal of Science and Research (IJSR) \\ ISSN (Online): 2319-7064}

Index Copernicus Value (2013): 6.14 | Impact Factor (2015): 6.391

Vilathgamuwa et al (2009) introduced adjustment and control of three stage paralleled $\mathrm{Z}$ source inverters for dispersed era applications with downsized research facility model. Operational examination and balance control of three level Z source inverters with upgraded outcome waveform quality were finished by Poh Chiang Loh et al (2009) with delegate delineations [21].

The execution of three level $\mathrm{Z}$ source inverters under quasi conductor disappointment conditions was assessed by Feng Gao et al (2009) and accepted it through a downsized research center model [17]. Controller outline for a ZSI based DG framework was introduced by Gajanayake et al (2009) to enhance power nature of conveyance frameworks. Recreation results were acquired utilizing MATLAB/Simulink/PLECS and consequently it was tentatively accepted utilizing a laboratory model [22].

Table 1: Comparisons of various modulation techniques for single-phase topologies [23], [24]

\begin{tabular}{|c|c|c|c|}
\hline \begin{tabular}{|c|} 
Modulation \\
Technique
\end{tabular} & $\begin{array}{l}\text { Switching } \\
\text { topology/no. } \\
\text { of switches }\end{array}$ & $\begin{array}{c}\text { Peak stress on } \\
\text { switching } \\
\text { devices } \\
\end{array}$ & Modulation signal \\
\hline $\begin{array}{l}\text { Non-linear } \\
\text { SPWM }\end{array}$ & $\begin{array}{l}\text { Quasi Z- } \\
\text { source/2 }\end{array}$ & $\begin{array}{l}\text { VSW=3Vin } \\
\text { ISW=3Iin }\end{array}$ & $\begin{array}{c}\text { One quasi sinusoidal } \\
\text { modulating signal } \\
\mathrm{v}=[2-\mathrm{M} \sin \omega \mathrm{t}]-1\end{array}$ \\
\hline One cycle & $\begin{array}{l}\text { Single- } \\
\text { phase/2 }\end{array}$ & $\begin{array}{l}\text { VSW=3Vin } \\
\text { ISW=3Iin }\end{array}$ & $\begin{array}{l}\text { One sinusoidal } \\
\text { modulating signal } \\
\text { (Vinvref), where } \\
\text { vref }=\mathrm{Vm} \sin \omega \mathrm{t}\end{array}$ \\
\hline \begin{tabular}{|c|} 
Carrier \\
based PWM
\end{tabular} & $\begin{array}{c}\text { 2-leg } \\
\text { Hbridge/4 }\end{array}$ & $\begin{array}{c}\text { VSW=BVin, } \\
\text { ISW=Bio } \\
\text { where } \mathrm{B}=[1- \\
\text { 2Dst }]-1\end{array}$ & $\begin{array}{c}\text { Two sinusoidal } \\
\text { modulating signals } \\
\mathrm{v}=\mathrm{M} \cos \omega \mathrm{t} \text { for } \\
\text { second leg }\end{array}$ \\
\hline $\begin{array}{c}\text { Hysteresis } \\
\text { Band } \\
\text { current } \\
\text { control } \\
\end{array}$ & $\begin{array}{c}\text { 2-leg } \\
\text { Hbridge/4 }\end{array}$ & $\begin{array}{c}\text { VSW=BVin, } \\
\text { ISW=Bio } \\
\text { where } \mathrm{B}=[1- \\
\text { 2Dst]-1 }\end{array}$ & $\begin{array}{c}\text { A Band of sinusoidal } \\
\text { modulating signals } \\
\text { vref }=V m \text { sin } \omega t\end{array}$ \\
\hline
\end{tabular}

Hanif et al (2011) clarified circuit counts, self-support marvel, inductor and capacitor plan estimations, help control techniques and gadget determination strategies of $\mathrm{Z}$ source inverter suited for solar light based photovoltaic frameworks with an outline illustration [23]. Vilathgamuwa et al (2009) exhibited a regulation and controller outline technique for paralleled Z-source inverter frameworks material for option energy sources like solar oriented cells, energy units, or variable-speed wind turbines with front-end diode rectifiers. The execution was accepted with simulations utilizing MATLAB/Simulink/Power sim and its model was worked to get its exploratory confirmations [20]. Relative simulation studies for three unique topologies of two level voltage sort $\mathrm{Z}$ source inverters under four diverse switching plans viz., straightforward help, greatest support, most extreme consistent help, and adjusted space vector PWM control were completed by Omar Ellabban et al (2009) with an outline case for cross breed electric vehicles [24].

Sumedha Rajakaruna et al (2010) introduced rules to outline the impedance organize precisely for the situation where the inverter is worked just in dynamic and shoot through states and it can be utilized to anticipate the basic estimations of capacitance and inductance [25].

\section{Reviewed Outcomes}

Following outcomes are reviewed from above literature survey:

The Z-source inverter (ZSI) presents another single-stage structure to accomplish the voltage help/buck character in a solitary power transformation stage. This sort of converter can deal with the PV dc voltage varieties over a wide range without exaggerating the inverter. Therefore, the segment tally and framework expense are diminished, with enhanced unwavering quality because of the permitted shoot through state. Recently proposed quasi Z-source inverters (QZSI) have some new appealing favorable circumstances more reasonable for application in PV frameworks. Quasi Zsource inverter (QZSI) is a power transformation innovation reasonable for interfacing of renewable sources [26].

Two methodologies are with the related configuration standards to control the new energy put away QZSI when connected to the PV power framework. They can control the inverter outcome power, track the PV board's most extreme power point, and deal with the battery power, all the while. QZSI draws a steady current from the PV board, and along these lines, there is no requirement for additional separating capacitors. The voltage support and reversal, and energy storage are incorporated in a solitary stage inverter [27].

Quasi Z-Source Inverter: The quasi z-source inverter (QZSI) is a solitary stage power converter got from the Z-source inverter topology, utilizing an interesting impedance system. The customary VSI and CSI experience the ill effects of the impediment that activating two switches in the same leg or stage prompts a source short and also, the most extreme possible outcome voltage can't surpass the dc contribution, since they are buck converters and can create a voltage lower than the dc info voltage [28].

\section{Conclusions}

A quasi Z-source inverter with battery for photovoltaic power generation framework was proposed. In this framework the battery was paralleled with one of the capacitors specifically to store or discharge energy, with no additional parts. The power change circuit of qZSI with battery framework was broke down. The connections among PV power, battery power, and inverter power, and among two inductor streams and battery current were determined. In this paper we have reviewed a number of existing techniques based on control and analysis of QZSI grid connected systems.

\section{References}

[1] Peng FZ, Shen MS, Holland K. Application of Z-source Inverter for traction drive of fuel cell - battery hybrid electric vehicles. IEEE Trans Power Electron 2007; 22(3):1054-61.

[2] Peng FZ. Z-source inverter. IEEE Trans Indust Appl 2003;39(2):504-10.

[3] X. Wang, Z. Fang, J. Li, L. Wang, and S. Ni,"Modeling and control of dual-stage high-power multifunctional 


\section{International Journal of Science and Research (IJSR) \\ ISSN (Online): 2319-7064}

Index Copernicus Value (2013): 6.14 | Impact Factor (2015): 6.391

PVsystem in $d-q-o$ coordinate," IEEE Trans. Ind. Electron., vol. 60, no. 4, pp. 1556-1570, Apr. 2013.

[4] B. Indu Rani, G. Saravana Ilango, and C. Nagamani,"Control strategy for power flow management in a PV system supplying DC loads," IEEE Trans. Ind. Electron., vol. 60, no. 8, pp. 31853194, Aug. 2013.

[5] S. Sreeraj,K. Chatterjee, and S. Bandyopadhyay "One cycle controlled single-stage, single-phase voltage sensor-less grid-connected PV system," IEEE Trans. Ind. Electron., vol. 60, no. 3, pp. 1216-1224, Mar. 2013.

[6] J. Chavarria, D. Biel, F. Guinjoan, C. Meza, and J. Negroni, "Energy balance control of PV cascaded multilevel grid-connected inverters for phase-shifted and level shifted pulse-width modulations," IEEE Trans. Ind. Electron, vol. 60, no. 1, pp. 98-111, Jan. 2013.

[7] G. Petrone,G. Spagnuolo, and M. Vitelli, "An analog technique for distributed MPPT PV applications," IEEE Trans. Ind. Electron., vol. 59 no. 12, pp. 4713-4722, Dec. 2012.

[8] D. Vinnikov,I. Roasto, R. Strzelecki, and M. Adamowicz, "Step-up DC/DC converters with cascaded quasi-z-source network," IEEE Trans. Ind. Electron, vol. 59, no. 10, pp. 3727-3736, Oct. 2012.

[9] J. Chavarria, D. Biel, F. Guinjoan, C. Meza, and J. Negroni, "Energy balance control of PV cascaded multilevel grid connected inverters for phase-shifted and level-shifted pulse-width modulations," IEEE Trans. Ind. Electron., vol. 60, no. 1, pp. 98-111, Jan. 2013.

[10]D. Vinnikov, I. Roasto, R. Strzelecki, and M. Adamowicz, "Step-up DC/DC converters with cascaded quasi-z-source network," IEEE Trans. Ind. Electron., vol. 59, no. 10, pp. 3727-3736, Oct. 2012.

[11] G. Petrone, G. Spagnuolo, and M. Vitelli, "An analog technique for distributed MPPT PV applications," IEEE Trans. Ind. Electron., vol. 59, no. 12, pp. 4713-4722, Dec. 2012.

[12]D. Vinnikov and I. Roasto, "Quasi-Z-source-based isolated DC/DC converters for distributed power generation," IEEE Trans. Ind. Electron., vol. 58, no. 1, pp. 192-201, Jan. 2011.

[13]D. Vinnikov and I. Roasto, "Quasi-Z-source-based isolated DC/DC converters for distributed power generation," IEEE Trans. Ind. Electron., vol. 58, no. 1, pp. 192-201, Jan. 2011.

[14]F. Bradaschia, M. C. Cavalcanti, P. E. P. Ferraz, F. A. S. Neves, E. C. dos Santos, and J. H. G. M. da Silva, "Modulation for three-phase transformer less Z-source inverter to reduce leakage currents in photovoltaic systems," IEEE Trans. Ind. Electron., vol. 58, no. 12, pp. 5385-5395, Dec. 2011.

[15] W. Li and X. He, "Review of nonisolated high-step-up DC/DC converters in photovoltaic grid- connected applications," IEEE Trans. Ind. Electron., vol. 58, no. 4, pp. 1239-1250, Apr. 2011.

[16] Q.Tran, T.Chun, J. Ahn, and H.-H. Lee, "Algorithms for controlling both the DC boost and AC output voltage of Zsource invert-er," IEEE Trans.Ind. Electron. vol. 54, no. 5, pp. 2745-2750, Oct. 2007.
[17] C. J. Gajanayake, D. M. Vilathgamuwa, and C. L. Poh, "Development of a comprehensive model and a multi loop controller for Z-source inverter DG systems," IEEE Trans. Ind. Electron., vol. 54, no. 4, pp. 23522359, Aug. 2007.

[18] M. Shen, J. Wang, A. Joseph, F. Z. Peng, L. M. Tolbert, and D. J. Adams, "Constant boost control of the $\mathrm{Z}$ source inverter to mini-mize current ripple and voltage stress,"IEEETrans.Ind.Appl.,vol. $\quad$ 42,no.3,pp.770778,May/Jun. 2006.

[19]Huang Y, Shen MS, Peng FZ, Wang J. Z-source inverter for residential photovoltaic systems. IEEE Trans Power Electron 2006; 21(6):1776-82.

[20]Badin R, Huang Y, Peng FZ, Kim HG. Grid interconnected Z-source PV system. In: Proceedings of IEEE power electronics specialist's conference, Orlando, USA; 2007. p. 2328-33.

[21] C. J. Gajanayake, D. M. Vilathgamuwa, and C. L. Poh, "Development of a comprehensive model and a multi loop controller for Z-source inverter DG systems," IEEE Trans. Ind. Electron., vol. 54, no. 4, pp. 23522359, Aug. 2007.

[22] Li Y, Anderson J, Peng FZ, Liu DC. Quasi-Z-source inverter for photovoltaic power generation systems. In: Proceedings of the twenty-fourth annual IEEE applied power electronics conference and exposition, Washington (DC, USA); 2009. p. 918-24.

[23] Bradaschia F, Cavalcanti MC, Ferraz PEP, Neves FAS, dos Santos EC, da Silva JHGM. Modulation for threephase transformerless Z-source inverter to reduce leakage currents in photovoltaic systems. IEEE Trans Indust Electron 2011;58(12):5385-95.

[24] Vinnikov D, Roasto I. Quasi-Z-source-based isolated DC/DC converters for distributed power generation. IEEE Trans Indust Electron 2011;58(1):192-201.

[25] Anderson J, Peng FZ. Four quasi-Z-source inverters. In: Proceedings of IEEE power electronics specialist's conference, Rhodes, Greece; 2008. p. 2743-9.

[26] Park JH, Kim HG, Nho EC, Chun TW, Choi J. Gridconnected PV system using a quasi-Z-source Inverter. In: Proceedings of the twenty-fourth annual IEEE applied power electronics conference and exposition, Washington (DC, USA); 2009. p. 925-9.

[27] Peng FZ, Shen MS, Holland K. Application of Z-source Inverter for traction drive of fuel cell - battery hybrid electric vehicles. IEEE Trans Power Electron 2007; 22(3):1054-61.

[28] Peng FZ. Z-source inverter. IEEE Trans Indust Appl 2003; 39(2):504-10. 